\title{
TINJAUAN YURIDIS NORMATIF PERJUDIAN ONLINE MENURUT HUKUM POSITIF DI INDONESIA
}

\author{
Oleh \\ Enik Isnaini \\ Dosen Fakultas Hukum Universitas Islam Lamongan
}

\begin{abstract}
ABSTRAK
Fenomena perjudian merupakan suatu bentuk permasalahan sosial yang telah ada sejak zaman dahulu. Selain bertentangan dengan nilai dan norma yang ada dalam masyarakat, perjudian juga memberikan dampak buruk dalam kehidupan pribadi maupun dalam kelompok masyarakat. seiring dengan perkembangannya, perjudian dengan bersaranakan teknologi atau perjudian online tumbuh dan berkembang seiring semakin bertambahnya para pengguna alatalat komunikasi elektronik yang berbasis internet. Pemerintah dalam fungsinya sebagai pengawasan sosial (social control) telah menetapkan aturan-aturan mengenai perjudian dalam rumusan peraturan perundang-undangan yang ada. pengaturan hukum terhadap tindak pidana perjudian telah diatur dalam Pasal 303 KUHP dan Pasal 303 bis KUHP. sedangkan sanksi pidanannya diperberat sesuai dalam Pasal 2 ayat (1), (2), (3) Undang-Undang Nomor 7 tahun 1974 tentang Penertiban Perjudian. Apabila telah terbukti melakukannya maka dapat diproses sesuai dengan hukum acara yang berlaku. kebijakan penegakan hukum terhadap tindak pidana perjudian online dalam upaya penegakan hukum terhadap tindak perjudian online, dilaksanakan dengan berdasarkan kepada ketentuan pasal 27 ayat (2) dan pasal 45 ayat (1) Undang-Undang Nomor 11 Tahun 2008 Tentang Informasi dan Transaksi Elektronik. namun pada kenyataannya penyidik Kepolisian Negara Republik Indonesia masih sering menggunakan pasal 303 KUHP untuk pelaku tindak pidana perjudian online karena kesulitan menerapkan pasal 43 ayat (6) Undang-Undang Nomor 11 tahun 2008 yaitu yaitu adanya ketentuan penyidik dalam melakukan penangkapan dan penahanan melalui penuntut umum meminta penetapan Ketua Pengadlan Negeri setempat dalam waktu satu kali dua puluh empat jam. maka sudah sepatutnya diperlukan pembuatan undang-undang atau penyempurnaan ketentuan yang telah ada.
\end{abstract}

Kata Kunci : Tinjauan Yuridis, Perjudian Online,Hukum Positif Indonesia.

\section{PENDAHULUAN}

\section{Latar Belakang Masalah}

Kemajuan dalam bidang ilmu pengetahuan dan tekhnologi (IPTEK) telah meningkatkan pula modus kejahatan yang ada. saat ini modus kejahatan tidak hanya dilakukan di dunia nyata, melainkan juga melalui internet, atau sering disebut dengan kejahatan dunia cyber (cyber crime). Kemajuan ilmu pengetahuan dan teknologi pula yang turut mempengaruhi cara berpikir, bersikap dan bertindak. perubahan cara pandang dan penilaian dalam masyarakat inilah yang mempengaruhi kesadaran hukum akan penilaian terhadap suatu perilaku, apakah perbuatan tersebut dianggap patut atau bahkan sebaliknya, merupakan suatu ancaman bagi ketertiban umum.

Fenomena perjudian memang telah ada sejak dahulu kala. bahkan dalam masyarakat adat tertentu, perjudian dianggap sebagai suatu tradisi warisan leluhur yang harus 
dilestarikan. tetapi sebenarnya perjudian merupakan patologi sosial karena bertentangan dengan nilai dan norma yang ada di masyarakat.

Dengan semakin banyaknya situs-situs perjudian di internet juga kemudahan akses dan transaksinya, yaitu melalui transaksi elektronik perbankan, membuat aparat penegak hukum kesulitan dalam pengusutannya. dengan bermacam kemudahan yang ditawarkan melalui situs-situs perjudian tersebut membuat banyak kalangan tertarik untuk mencoba peruntungannya dengan maksud memperoleh keuntungan besar. namun secara tidak disadari perjudian menyebabkan bermacam permasalahan sosial dan ketergantungan untuk ingin terus menerus mencoba, sehingga melupakan kewajiban dan tanggung jawabnya dalam kehidupan pribadi maupun dalam bermasyarakat. bagi pelaku yang kalah berjudi akan menimbulkan rasa penasaran ingin mencoba lagi hingga mengakibatkan hutang dan kemiskinaan yang memicu meningkatnya angka kriminalitas. maka baik secara langsung maupun tidak langsung perjudian tetap menimbulkan dampak negatif yang merugikan bagi kehidupan.

\section{METODE PENELITIAN Tipe Penelitian}

Tipe penelitian yang di gunakan dalam penelitian ini adalah metode penelitian hukum normatif atau peneltian hukum kepustakaan. yaitu penelitian hukum yang dilakukan dengan cara meneliti bahan pustaka yaitu data primer maupun sekunder. bahan-bahan hukum tersebut disusun secara sistematis guna mempermudah dalam mengambil kesimpulan dari permasalahan yang diteliti.

\section{Pendekatan Masalah}

Dalam pendekatan masalah ini menggunakan metode pendekatan Yuridis Normatif. Pendekatan ini adalah pendekatan terhadap perundang-undangan yang berlaku. pendekatan UndangUndang (statue approach) dilakukan dengan menelaah semua undang-undang dan regulasi yang bersangkut-paut dengan isi hukum yang sedang ditangani. ${ }^{25}$

Pendekatan masalah yuridis normatif merupakan pendekatan yang digunakan dengan melakukan pendekatan peraturan perundangundangan (statue approach), pendekatan tersebut melakukan pengkajian peraturan perundangundangan yang berhubungan dengan permasalahan yang diteliti. selain itu juga digunakan pendekatan konsep (conseptual approach) untuk melihat konsepkonsep hukum yang terkait dengan permasalahan yang ada.

\section{HASIL PENELITIAN DAN \\ PEMBAHASAN \\ Pengaturan hukum terhadap tindak pidana perjudian menurut KUHP \\ .Pemidanaan dalam kasus} perjudian telah diatur dalam Pasal 303 KUHP dan Pasal 303 bis KUHP. dalam penjelasan Undang-Undang Nomor 7 tahun 1974 pasal 1 menyatakan adanya pengklasifikasian terhadap segala macam bentuk tindak pidana perjudian sebagai kejahatan dan memberatkan ancaman hukumannya. ancaman yang berlaku terdahulu ternyata sudah tidak sesuai lagi dan tidak membuat pelakunya jera. $^{26}$

Salah satu ketentuan yang merumuskan ancaman terhadap tindak pidana perjudian ada dalam pasal 303

\footnotetext{
25 Peter Mahmud Marzuki, Penelitian Hukum, Kencana, Jakarta, 2011. h.93

$26 \quad$ Sugeng Tiyarto, Op.Cit. h.28
} 
dan 303 bis KUHP yang telah diubah dalam Pasal 2 ayat (1), (2) dan (3) Undang-Undang Nomor 7 Tahun 1974 . dalam Pasal tersebut menyatakan :

(1) Merubah ancaman hukuman dalam pasal 303 ayat (1) Kitab Undang- Undang Hukum Pidana, dari hukuman penjara selamalamanya dua tahun delapan bulan atau denda sebanyak-banyaknya Sembilan puluh ribu rupiah menjadi hukuman penjara selamlamanya sepuluh tahun atau denda sebanyak-banyaknya dua puluh lima juta rupiah.

(2) Merubah ancaman hukuman dalam pasal 303bis ayat (1) Kitab Undang-Undang Hukum Pidana, dari hukuman kurungan selamalamanya satu bulan atau denda sebanyak-banyaknya empat ribu lima ratus rupiah menjadi hukuman penjara selama-lamanya empat tahun atau denda sebanyak-banyaknya sepuluh juta rupiah.

(3) Merubah ancaman hukuman dalam pasal 303 bis ayat (2) Kitab Undang-Undang Hukum Pidana, dari hukuman kurungan selamalamanya tiga bulan atau denda sebanyak-banyaknya tujuh ribu lima ratus rupiah menjadi hukuman penjara selama-lamanya enam tahun atau denda sebanyakbanyaknya lima belas juta rupiah.

Salah satu ketentuan yang merumuskan ancaman terhadap tindak pidana perjudian yaitu pasal 303 ayat (1) yang didalamnya memuat unsur tanpa izin, dengan demikian maka perjudian dapat digolongkan menjadi dua macam yaitu :

1. Perjudian yang bukan merupakan tindak pidana kejahatan apabila pelaksanaannya telah mendapat izin terlebih dahulu dari pejabat yang berwenang, seperti :

a. Kasino dan Petak Sembilan di Jakarta dan Sari Empat di jalan kelenteng Bandung. b. Toto (Totalisator) Grey Hound di Jakarta (ditutup 1 Oktober 1978 oleh pemerintah DKI).

c. Undian harapan yang sudah berubah menjadi Undian Sosial Berhadiah, pusatnya ada di Jakarta. di Surabaya ada undian Sampul Rejeki, Sampul Borobudur di Solo, Sampul Danau Toba di Medan, Sampul Sumber Harapan di Jakarta, semuanya berhadiah 80 juta rupiah. $^{27}$

Dari contoh perjudian tersebut bukanlah merupakan kejahatan karena sudah mendapatkan izin dari pemerintah daerah atau pemerintah setempat dengan berlandaskan pada Undang-Undang Nomor 22 Tahun 1954 tentang Undian. menurut Pasal 1 dan 2 Undang-Undang Nomor 22 Tahun 1954 mengizinkannya apabila undian yang diadakan tersebut diadakan oleh

a. Negara;

b. Oleh suatu perkumpulan yang diakui sebagai badan hukum, atau oleh suatu perkumpulan yang terbatas pada para anggota untuk keperluan sosial, sedang jumlah harga nominal dari undian tersebut tidak lebih dari Rp. 3.000,00 (Tiga Ribu Rupiah).

Undian tersebut harus diberitahukan kepada instansi pemerintah yang berwajib dalam hal ini kepalah daerah, izin untuk mengadakan undian hanya dapat diberikan untuk keperluan sosial yang bersifat umum.

2. Perjudian yang merupakan tindak pidana kejahatan, apabila pelaksanaannya tanpa mendapat izin terlebih dahulu dari pejabat yang berwenang. dalam pasal 303 bis KUHP menyebut unsurunsurnya sebagai berikut : 
a. Menggunakan kesempatan untuk main judi;

b. Dengan melanggar ketentuan pasal 303 KUHP.

KUHP secara spesifik telah mengatur tindak pidana perjudian dan menggolongkan perjudian kedalam buku II bab XIV sebagai kejahatan kesusilaan. Larangan-larangan perjudian telah dirumuskan ancaman pidana dan penjelasannya dalam pasal 303 KUHP sebagai berikut :

(1) Diancam dengan pidana penjara paling lama sepuluh tahun atau pidana denda paling banyak dua puluh lima juta rupiah, barangsiapa tanpa mendapat izin;

1. Dengan sengaja menawarkan atau memberikan kesempatan untuk permainan judi dan menjadikannya sebagai pencaharian, atau dengan sengaja turut serta dalam suatu perusahaan untuk itu;

2. Dengan sengaja menawarkan atau member kesempatan kepada khalayak umum untuk bermain judi atau dengan sengaja turut serta dalam perusahaan untuk itu, dengan tidak perduli apakah untuk menggunakan kesempatan adanya suatu syarat atau dipenuhinya sesuatu tata cara;

3. Menjadikan turut serta pada permainan judi sebagai percaharian.

(2) Kalau yang bersalah melakukan kejahatan tersebut dalam menjalankan pencahariannya, maka dapat dicabut haknya untuk menjalankan pencaharian itu.

(3) Yang disebut dengan permainan judi adalah tiap-tiap permainan, dimana pada umumnya kemungkinan mendapatkan untung bergantung pada keberuntungan belaka, juga karena pemainnya lebih terlatih atau lebih mahir. Disitu termasuk segala pertaruhan tentang keputusan perlombaan atau permainan lain-lainnya yang tidak diadakan antara mereka yang turut berlomba atau bermain. Demikian juga segala pertaruhan lainnya."

ermain judi hanya sebagai hiburan belaka.

Sedangkan dalam pasal 303 bis KUHP juga mengatur tentang perjudian yang menyatakan :

(1) Diancam dengan pidana penjara paling lama empat tahun atau pidana denda paling banyak sepuluh juta rupiah;

1. Barangsiapa menggunakan kesempatan main judi, yang diadakan dengan melanggar ketentuan pasal 303;

2. Barangsiapa ikut serta main judi di jalan umum atau di pinggir jalan umum atau di tempat yang dapat di kunjungi umum, kecuali kalau ada izin dari penguasa yang berwenang yang telah memberi ijin untuk mengadakan perjudian itu.

(2) Jika ketika melakukan pelanggaran belum lewat dua tahun sejak ada pemidanaan yang menjadi tetap karena salah satu dari pelanggaran ini, dapat dikenakan pidana penjara paling lama enam tahun atau pidana denda paling banyak lima belas juta rupiah."

Melihat rumusan peraturan hukum pidana tersebut berarti sudah jelas bahwa perjudian adalah dilarang oleh norma hukum pidana karena telah memenuhi rumusan seperti yang telah dijelaskan. sejak diberlakukannya Peraturan Pemerintah Nomor 9 Tahun 1981, pemerintah telah melarang pemberian izin bagi perjudian yang artinya segala jenis dan bentuk perjudian merupakan kegiatan illegal maka dapat dikenakan sanksi pidana yang pelaksanaannya diproses sesuai dengan hukum acara pidana. ${ }^{28}$

\footnotetext{
28 Sugeng Tiyarto, Op.Cit. h.36
} 
Kebijakan penegakan hukum terhadap tindak pidana perjudian online

. Kebijakan penegakan hukum pada hakikatnya merupakan bagian dari politik kriminal yang pada hakekatnya menjadi bagian integral dari kebijakan sosial (social policy), kemudian kebijakan ini diimplementasikan kedalam sistem peradilan pidana (criminal juctice system). sistem peradilan pidana mempunyai dimensi fungsional ganda. di satu pihak berfungsi sebagai sarana masyarakat untuk menahan dan mengendalikan kejahatan pada tingkatan tertentu (crime containment system), dilain pihak sistem peradilan pidana juga berfungsi untuk pencegahan sekunder (secondary prevention) yaitu mencoba mengurangi kriminalitas di kalangan mereka yang pernah melakukan tindak pidana dan mereka yang bermaksud melakukan kejahatan melalui proses deteksi, pemidanaan dan pelaksanaan pidana. $^{29}$ Sistem peradilan pidana tersebut didalam operasionalnya melibatkan sub sistemnya yang bekerja secara koheren, koordinatif, dan integratif, agar dapat mencapai efisiensi dan efektifitas yang maksimal. Oleh karena itu efisiensi maupun efektifitasnya sangat tergantung pada faktor-faktor sebagai berikut :

a. Infrastruktur pendukung sarana dan prasarana;

b. Profesionalisme aparat penegak hukum dan;

c. Budaya hukum masyarakat.

Secara konsepsional inti dari arti penegakan hukum terletak pada kegiatan menyerasikan hubungan nilai-nilai yang terjabarkan dalam kaidah-kaidah yang mantap dan mengejawantah sikap tindak sebagai rangkaian penjabaran nilai tahap akhir, untuk menciptakan, memelihara dan mempertahankan kedamaian pergaulan hidup. sebagai suatu proses penegakan hukum pada hakekatnya merupakan penerapan diskresi yang menyatakan pembuat keputusannya tidak secara ketat diatur oleh kaidah hukum akan tetapi mempunyai unsur penilaian pribadi.

Ada beberapa faktor yang mempengaruhi penegakan hukum, yaitu :

a.Faktor hukumnya sendiri;

b.Faktor penegak hukum;

c.Faktor sarana atau fasilitas yang mendukung penegakan hukum;

d.Faktor masyarakat;

e.Faktor kebudayaan. ${ }^{30}$

Kelima faktor diatas merupakan faktor-faktor yang terkait satu sama lain. Merupakan esensi dari penegakan hukum dan bekerjanya hukum dalam masyarakat. kaitannya dengan penegakan hukum terhadap tindak pidana perjudian online, efisiensi maupun efektifitasnya juga tergantung kepada faktor-faktor sebagaimana yang disebutkan meliputi :

a. Faktor Perundang-Undangan

Salah satu asas dalam hukum pidana menentukan bahwa tiada perbuatan yang dilarang dan diancam dengan pidana jikalau hal itu terlebih dahulu belum dinyatakan dalam suatu Peraturan Perundang-Undangan (asas legalitas). Secara opersional perundang-undangan pidana mempunyai kedudukan strategis terhadap system peradilan pidana. Sebab hal tersebut memberikan definisi tentang perbuatanperbuatan apa yang dirumuskan sebagai tindak pidana. Mengendalikan usaha-usaha pemerintah untuk memberantas kejahatan dan memidana si pelaku, 
memeberikan batasan tentang pidana yang dapat di terapkan untuk setiap kejahatan . dengan perkataan lain PerundangUndangan pidana menciptakan legislated environment yang mengatur segala prosedur dan tata cara yang harus dipatuhi didalam berbagai peringkat system peradilan pidana. ${ }^{31}$ pengaturan atas tindak pidana perjudian online telah dirumuskan dalam pasal 27 ayat (2) Juncto Pasal 45 ayat (1) UndangUndang Nomor 11 Tahun 2008 Tentang Informasi dan Transaksi Elektronik.

b. Faktor Penegak Hukum

Keberhasilan misi hukum pidana untuk menanggulangi tindak pidana perjudian online tidak hanya ditentukan oleh sempurnannya postulat hukum yang dirumuskan dalam hukum positif. Melainkan telah lebih dari itu keberhasilannya sangat tergantung kepada aparat yang melaksanakannya (penegak hukum) mulai dari tingkat penyidikan hingga tingkat eksekusi. aparat penegak hukum harus memiliki kemampuan lebih didalam melakukan penyidikan, pembuktian baik pada pemeriksaan pendahuluan maupun dalam proses peradilan. Pengetahuan dan wawasan yang luas atas delik materiil maupun peristiwa hukumnya serta kedisiplinan dan dedikasi yang tinggi dalam melaksanakan pemidanaannya.

c. Faktor Infrastruktur Pendukung Sarana dan Prasarana

Faktor ini dapat dikatakan sebagai tulang punggung penegakan hukum terhadap tindak pidana perjudian online. Sebab eksistensinya merupakan penopang keberhasilan untuk menemukan suatu kebenaran materiil. Oleh karena jalinan kerjasama yang haromis antara lembaga penegak hukum dengan beberapa pakar dan spesialis di bidangnya seperti ahli forensik, pakar telematika, serta dana operasional yang memadai adalah merupakan faktor pendukung guna mengadili dan memidana atau mempersempit ruang gerak pelaku tindak pidana perjudian online.

d. Faktor Budaya Hukum Masyarakat

Faktor budaya hukum masyarakat memiliki pengaruh dan memainkan peranan yang penting dalam proses penegakan hukum terhadap tindak pidana perjudian. pluralisme budaya hukum di tengah masyarakat merupakan fenomena yang unik dan mengandung resiko yang potensial, sehingga seringkali menempatkan posisi dan profesi aparat penegak hukum kedalam kondisi dilematis, yang pada gilirannya dapat mengakibatkan ambivalensi dalam melaksanakan peranan aktualnya.

Kepatuhan semua masyarakat terhadap hukum, ketidakdisiplinan sosial, tidak diindahkannya etika sosial, mudahnya anggota masyarakat tergiur oleh suatu bentuk perjudian yang menawarkan keuntungan diluar kelaziman dan sebagainya. adalah sederetan contoh dari bentuk-bentuk budaya hukum yang rawan serta potensial untuk terjadinya tindak pidana perjudian.

Syarat-syarat agar hukum lebih efektif dalam penerapannya, antara lain :

1. Undang-Undang harus dirancang dengan baik.

2. Undang-Undang seyogianya bersifat melarang bukan mengatur.

3. sanksi yang dicantumkan harus sepadan dengan sifat-sifat undangundang yang dilanggar. 
4. berat sanksi yang diancamkan kepada si pelanggar tidak boleh keterlaluan.

5. kemungkinan untuk mengamati dan menyelidiki atau menyidik perbuatan yang dilanggar undangundang harus ada.

6. hukum yang mengandung larangan-larangan moral akan lebih efektif dari pada hukum yang tidak selaras dengan kaidah moral, atau yang netral.

7. mereka yang bekerja sebagai pelaksana-pelaksana hukum harus menunaikan tugasnya dengan baik.

$\begin{array}{lrr}\text { maka } & \begin{array}{l}\text { Berdasarkan } \\ \text { pembuatan }\end{array} & \text { tersebut } \\ \text { perundang-undangan } & & \text { peraturan } \\ \text { harus }\end{array}$

dirumuskan secara rinci dan jelas mengatur dan member sanksi agar tidak menimbulkan keraguan dalam penerapannya agar tercipta suatu keadilan dan kepastian hukum bagi pihak pihak yang berperkara. ada banyak aktivitas yang dilakukan perlengkapan Negara dalam melaksanakan penegakan hukum yaitu kepolisian, kejaksaan, hakim, pembentuk undang-undang, institusi pemerintah dan aparat pelaksana pidana, yang kesemuanya mempunyai peranan untuk mencegah dan menanggulangi kejahatan.

Memperhatikan masalah penegak hukum ini jika dikaitkan dengan penegakan hukum terhadap tindak pidana perjudian online, maka aktifitas atau kegiatan yang dapat dilakukan sebagai upaya menghadapi masalah-masalah yang timbul dalam rangka penegakan hukum dan antisipasinya dapat meliputi pembuatan undang-undang atau penyempurnaan ketentuan yang sudah ada. tersedianya aparat penegak hukum yang memadai baik secara kuantitas maupun secara perorangan maupun kelompok.
Bedasarkan uraian yang telah dipaparkan diatas dapat dilihat bahwa efektifitas fungsionalisasi hukum pidana terhadap tindak pidana perjudian online tidak hanya terletak pada efisiensi dan efektifitas kinerja masing-masing sub sistem dalam peradilan pidana. melainkan juga tergantung pada dukungan sosial maupun kelembagaan dalam rangka pembentukan opini masyarakat tentang tindak pidana perjudian online dan sosialisasi hukum nasional secara luas.

Tindak pidana perjudian online hanya dikenakan ketentuan hukum yang ada dalam hal ini pasal 303 KUHP, padahal saat ini telah ada ketentuan yang mengatur tentang perjudian online dalam pasal 27 ayat (2) dan pasal 45 ayat (1) UndangUndang Nomor 11 tahun 2008 tentang Informasi dan Transaksi elektronik. Oleh karena itu kebijakan akan saling melengkapi menegenai peraturan mana yang dapat diberlakukan atas tindak pidana perjudian online. Penerapan pasal 303 KUHP atas tindak pidana perjudian online menimbulkan sulitnya proses pembuktian Karena dalam KUHP Tidak diatur adanya unsur-unsur yang mengandung teknologi informasi, sementara pada kasus perjudian online semua dilakukan dengan melalui media internet (cyber). Sementara itu, tidak diterapkannya pasal 27 ayat (2) dan pasal 45 ayat (1) Undang-Undang Nomor 11 Tahun 2008, disebabkan adanya prosedur penyidikan dalam pasal 43 ayat (6) Undang-Undang Nomor 11 Tahun 2008 yang sulit dilaksanakan, yaitu adanya ketentuan penyidik dalam melakukan penangkapan dan penahanan melalui penuntut umum meminta penetapan Ketua Pengadlan Negeri setempat dalam waktu satu kali dua puluh empat jam. dan hal tersebut tidak mungkin dilakukan, sehingga 
Kepolisian Negara Republik Indonesia sebagai penyidik terpaksa menetapkan ketentuan pasal 303 KUHP untuk menangani kasus perjudian online termaksud.

\section{KESIMPULAN DAN SARAN}

\section{Kesimpulan}

Berdasarkan hasil uraian
pembahasan pada bab-bab sebelumnya, maka penulis dapat menyimpulkan :

1. Bahwa pengaturan hukum terhadap tindak pidana perjudian telah diatur dalam Pasal 303 KUHP dan Pasal 303 bis KUHP. sedangkan sanksi pidanannya diperberat sesuai dalam Pasal 2 ayat (1), (2), (3) Undang-Undang Nomor 7 tahun 1974 tentang Penertiban Perjudian. Salah satu ketentuan yang merumuskan ancaman terhadap tindak pidana perjudian dalam pasal 303 ayat (1) yaitu adanya unsur tanpa izin, dengan demikian perjudian dapat digolongkan menjadi 2, yaitu perjudian yang bukan merupakan tindak pidana apabila pelaksanaannya telah mendapatkan izin dari pejabat yang berwenang dan perjudian yang merupakan tindak pidana yaitu dengan melanggar ketentuan dalam pasal 303 ayat (1) yaitu tanpa mendapat izin. Apabila telah terbukti melakukannya maka dapat diproses sesuai dengan hukum acara yang berlaku.

2. Bahwa kebijakan penegakan hukum terhadap tindak pidana perjudian online merupakan bagian dari politik kriminal yang diimplementasikan ke dalam sistem peradilan pidana yang berfungsi sebagai penahan dan pengendalian terhadap kejahatan dan sebagai pencegahan sekunder. yang berfungsi untuk menyerasikan hubungan nilainilai dalam kaidah-kaidah yang berlaku dengan tujuan untuk menciptakan, memelihara dan mempertahankan kedamaian pergaulan hidup. Yang dilaksanakan oleh alat perlengkapan Negara yaitu Kepolisian, kejaksaan, hakim, pembentuk undang-undang, institusi pemerintah dan aparat pelaksana pidana. dalam upaya penegakan hukum terhadap tindak perjudian online, dilaksanakan dengan berdasarkan kepada ketentuan pasal 27 ayat (2) dan pasal 45 ayat (1) UndangUndang Nomor 11 Tahun 2008 Tentang Informasi dan Transaksi Elektronik. namun pada kenyataannya penyidik Kepolisian Negara Republik Indonesia masih sering menggunakan pasal 303 KUHP untuk pelaku tindak pidana perjudian online karena kesulitan menerapkan pasal 43 ayat (6) Undang-Undang Nomor 11 tahun 2008 yaitu yaitu adanya ketentuan penyidik dalam melakukan penangkapan dan penahanan melalui penuntut umum meminta penetapan Ketua Pengadlan Negeri setempat dalam waktu satu kali dua puluh empat jam. maka sudah sepatutnya diperlukan pembuatan undangundang atau penyempurnaan ketentuan yang telah ada.

\section{Saran}

Adapun saran yang dapat diberikan oleh penulis dalam penulisan penelitian ini adalah:

1. Seharusnya pengaturan hukum terhadap tindak pidana perjudian bukan ditentukan kepada unsur tanpa izin tetapi harus ditentukan 
oleh unsur obyeknya, artinya pemidanaan terhadap para pelaku tindak pidana perjudian ditentukan karena memang perbuatan bermain judi adalah dilarang dan bersifat melawan hukum. Dan sifat pertanggung jawaban pidananya harus pula dibebankan kepada korporasi (rechtpersoonlijkheid) dan bukan hanya dibebankan kepada orangperorangan (natuurlijke person).

2. Kebijakan penegakan hukum terhadap tindak pidana perjudian online harus dilakukan dengan perumusan peraturan perundangundangan yang baru dan pernyempuranaan ketentuan yang telah ada. selain itu diperlukan upaya pencegahan yaitu dengan pemblokiran terhadap situs-situs yang memiliki muatan perjudian sebagai bagian dari upaya pemerintah dalam pemberantasan tindak pidana perjudian online.

\section{DAFTAR PUSTAKA}

\section{Literatur}

Adami Chazawi, Tindak Pidana Informasi \& Transaksi Elektronik, Media Nusa Creative, Malang, 2015 .

Carson Butcher, Abnormal Psychology And Modern Life, Collins Publisher Inc, New York, 1992.

C.S.T. Kansil, Pengantar Ilmu Hukum Dan Tata Hukum Indonesia, Balai Pustaka, Jakarta, 1989.

Ensiklopedia Indonesia, Cipta Adi Pustaka, Jakarta, 1980.

Kartini Kartono, Patologi Sosial, Raja Grafindo Persada, Jakarta, 2005.

Moeljatno, Asas-Asas Hukum Pidana, Rineka Cipta. Jakarta, 2002.
Peter Mahmud Marzuki, Penelitian Hukum, Kencana, Jakarta, 2011

R. Abdoel Djamali, Pengantar Hukum Indonesia, Raja Grafindo Persada, Jakarta, 2013.

Sugeng Tiyarto, Penegakan Hukum Terhadap Tindak Pidana Perjudian, Genta Press, Yogyakarta, 2015.

\section{Perundang-Undangan}

Kitab Undang-Undang Hukum Pidana (KUHP).

Kitab Undang-Undang Hukum Acara Pidana (KUHAP).

Undang-Undang Nomor 7 Tahun 1974 Tentang Penertiban Perjudian.

Undang-Undang Nomor 11 Tahun 2008 Tentang Informasi dan Transaksi Elektronik.

Peraturan Pemerintah Nomor 9 Tahun 1981 Tentang Pelaksanaan UndangUndang Nomor 7 Tahun 1974 tentang Penertiban Perjudian.

\section{INTERNET}

Andri Kristiawan, (2013), Kebijakan Hukum Cybercrime, http://etikadalamduniait.blogsp ot.com/, Diakses Pada Tanggal 19 Juni 2017.

http://dasarkepo.com/sejarah-judi-diindonesia-dari-zamankerajaan/, Diakses Pada Tanggal 12 Juni 2017.

http://freelist.org/cgibin/judi:hiprokrisi,lokalisasi,leg alisasi/, Diakses Pada Tanggal 11 Juni 2017.

Joshua Sitompul, (2013), Landasan Hukum Penanganan Cyber 
Crime,

http://m.hukumonline.com/,

Diakses Pada Tanggal 17 Juni 2017.

Johanes Papu, (2002), Perilaku Berjudi, http://epsikologi.com/, Diakses Pada Tanggal 13 Juni 2017.

http://kbbi.web.id/internet/, Diakses Pada Tanggal 11 Juni 2017.

http://kbbi.web.id/judi/, Diakses Pada Tanggal 11 Juni 2017.

http://kbbi.web.id/distribusi/, Diakses Pada Tanggal 06 Juli 2017.

http://kbbi.web.id/transmisi/, Diakses Pada Tanggal 06 Juli 2017. http://kbbi.web.id/akses/, Diakses Pada Tanggal 06 Juli 2017.

http://kominfo.go.id/penggunainternet-indonesia-nomor- enam-dunia/, Diakses Pada Tanggal 11 Juni 2017.

M. Yamin, (2012), Seminar Menyikapi Perjudian Online di Auditorium RRI, Jakarta, http://teknologi.news.viva.co.id /, Diakses Pada Tanggal 19 Juni 2017.

Onno W. Purbo, (2007), Kebangkitan Nasional ke-2 Berbasis Teknologi Informasi, Computer Network Research Group, ITB, http://yc1daf@garuda.drn.go.id/ , Diakses Pada Tanggal 19 Juni 2017.

http://purplenitadyah.wordpress.com/, Diakses Pada Tanggal 12 Juni 2017. 